


\title{
PERFORMANCE OF INTEGRATED CONTRACT AND INDEPENDENT BROILER PRODUCTION IN EAST LOMBOK, WEST NUSA TENGGARA
}

\author{
B. Indarsih ${ }^{1}$ and W. Suryatman ${ }^{2}$ \\ ${ }^{1}$ Faculty of Animal Science, University of Mataram, \\ Jl. Majapahit No. 62 Mataram 83125, NTB - Indonesia \\ ${ }^{2}$ Departments of Agriculture and Livestock Services, \\ Jl. Dr. Cipto Mangunkusumo No. 1 Selong, East Lombok, NTB - Indonesia \\ Corresponding E-mail:budiindarsih@gmail.com
}

Received January 02, 2012; Accepted February 18, 2012

\begin{abstract}
ABSTRAK
Penelitian ini dilakukan untuk mengetahui penampilan produksi broiler pada intergrasi vertikal (pola kemitraan) dan pola mandiri di Kabupaten Lombok Timur, Provinsi Nusa Tenggara Barat yang dilaksanakan bulan Juli sampai September 2011. Data primer diperoleh dari survai lapangan bersumber pada peternak pola kemitraan dan peternak mandiri. Tiga puluh peternak pola kemitraan berdasarkan skala pemeliharaan dan empat belas peternak mandiri dipilih sebagai sampel untuk mengukur penampilan numerikal dan pendapatan peternak. Hasil penelitian menunjukkan bahwa penampilan produksi broiler pola kemitraan dan mandiri masing-masing 315.7 and 317.1, dan angka ini lebih baik dari standar yaitu 200. Pendapatan peternak pola kemitraan lebih rendah dibanding pendapatan peternak mandiri dihitung berdasarkan satu siklus pemeliharaan pada saat studi ini dilakukan. Pola kemitraan menarik berbagai kalangan profesi, dan terbanyak melibatkan lulusan strata1 (43.3\%) sedangkan pola usaha mandiri diminati oleh kelompok tingkat pendidikan SMU (50\%) dengan pengalaman lebih dari 20 tahun.
\end{abstract}

Katakunci : kemitraan, mandiri, peternak, performan

\begin{abstract}
This study was undertaken to evaluate the performance of vertical integration and independent poultry producers in East Lombok, West Nusa Tenggara, during the period July to September 2011. Data was collected from a primary field survey of integrated contract and independent producers. The sample producers were interviewed to collect the required data using a questioner. Supporting data were obtained from the relevant institution, and poultry association. Thirty integrated contract and fourteen independent growers were involved to measure farm's performance with references on numerical performance (NP) and farmer' returns. This study indicates that the NP of integrated contract and independent farms were 315.7 and 317.1, respectively, both was higher than the standard that is 200 . Returns for integrated contract farmers were lower than the independent when calculated based on the production cycle when this study was undertaken. Integrated contract farmers were attractive to various types of professions, the graduated people of university or college $(43.3 \%)$ was the most, whilst independent farmers were dominated by senior high school (50\%) with higher experience which was more than 20 years.

Key words : integrated contract, independent, farmers, performance
\end{abstract}

\section{INTRODUCTION}

Poultry segment is one of the farm commodities since 1972 which experienced relatively rapid growth before the financial crisis that hit Indonesia in 1997. The growth of poultry industry was driven by the strong development of the upstream industries (feed mills, breeding farms and veterinary industries) and the downstream industries including chicken slaughter houses, processing plant to fulfill the demand of restaurants, hotels, fast food etc. The highest growth was observed in broiler industry which increased by 8.7 percent per year even this type of chickens in the period 2007-2008 experienced extremely sharp growth which 
reached 20.6 percent per year. The broiler industry is still dominant in contributing to the national production of poultry meat and continues to increase. The advantages of this industry as a substitute meat are a relatively short life cycle, advanced and established technologies and promising agribusiness systems. Another important contribution to the country is the availability of new job opportunities and improving the welfare of society.

The poultry development in the province of West Nusa Tenggara (NTB) experienced some fluctuations, even it tends to decrease. East Lombok is one of important regions in NTB, located $75 \mathrm{~km}$ from the province and relied upon in broiler production. The total broiler population in this region considerably increased in the last five years from 263,795 birds in 2006 to $1,126,845$ birds in 2010 or 4.2 times in an increase. The development of broiler agribusiness in this province in general and East Lombok in particular cannot be separated from the existence of several commercial broiler companies or integrators since 1999 as a partnership for farmers. The number of scientific works relating to an economic analysis and non-economic of the contract farming has revealed that contract farmers were advantageous over farmers operating independently (Tatlidil and Aktũrk, 2004; Begum, 2005; Goodwin et al., 2005; Simmons et al., 2005; Sriboonchitta and Wiboonpoongse, 2008). Surprisingly, it has been criticized that contract broiler farming is exploitative business to the broiler farmers (Thamizh and Rao, 2009).

However, the development of the broiler industry in the model of vertical integration in developing countries such as Indonesia could be different from one province or region to other regions because of significant regional variation in the poultry demand and the socio-economic environment. Therefore, this study was carried out to evaluate performance and profitability of vertically integrated contract and independent poultry farming systems in East Lombok by analyzing costs and returns and gathering some relevant information in order to optimize positively the existence of the systems in a long term.

\section{MATERIALS AND METHODS}

\section{Data Collection}

The data used in this study were collected covering East Lombok district from July to September 2011 production period. The techniques of data collection were field survey and types of data used were the primary and secondary data. The primary data were obtained through observations and interviews directly to farmers as well as the firms using a questionnaire. Characteristics of the respondents were age, formal education and experience of raising broilers, input of production cost, revenues and problems in the broiler farming. While the data from the firms included profiles of farmers as a grower, the rules and implementation of the contracted agreement, the contract price and marketing scheme. Secondary data were information of relevant institutions, such as the Department of Agriculture and Livestock, Poultry Association, Poultry Company and the Central Bureau of Statistics (BPS).

\section{Sample Determination}

A contract farming arrangement in broiler production is generally a wage contract between an "integrator", who supplies the intermediate inputs and procures the output, and a poultry farmer, who provides the primary inputs in the production process. The integrator provides day old chicks, feed, veterinary supplies and technical services, and arranging the final marketing of the output. The contract farmer provides the space or land for housing and poultry facilities, litter material, labour and day-to-day farm management (SAPPLPP, 2009).

The preliminary surveys showed that the number of broiler farmers in East Lombok was 78 consisting of 64 integrated contract and 14 independent farmers. Stratified random sampling method was used based on the farm scale to determine the sample of integrated contract farmers, then 10 respondents were randomly taken from each integrator. A representative sample was categorized according to their poultry farm sizes. Purposive sampling method was imposed to collect data for the independent farmers.

\section{Data Analysis}

The method of analysis used was qualitative and quantitative. Review of the implementation of the partnership program on broiler farms in East Lombok was conducted through analysis of qualitative descriptive approach. Analyses were performed on the mechanisms and patterns as well as the implementation of the rules of 
partnership. Quantitative analysis of the successful broiler farm production was measured by using Numerical Performance (NP), which is the most common formula used to determine the performance of commercial broilers and calculated using the following formula :

$\mathrm{NP}=(100 \%$ - percentage of mortality $) \mathrm{x}$ average body weight at marketing $\mathrm{x} 100$ FCR $\mathrm{x}$ age at marketing

Where:

FCR is the quantity of feed consumed for gain or live weight

The depreciation of housing and equipment was calculated using straight-line method (Siregar, 2008). Farmers' income was calculated from the difference between revenue and expenses. Revenue consisted of sales of broilers, is the total product multiplied by price at marketing and incentives. The incentive payment is a bonus received by the individual farmer due to above performance during a specific period of time. While the total expenditure is the total value of poultry production facilities use either acquired by cash, lease or loan during the production process takes place.

In this study, the returns at the broiler farm is net cash farm income received by farmers from the broiler farming business plus incentives and other revenues such as selling the used feed bags and poultry manure as a fertilizer. While independent farms, the income derived from harvesting chickens, used feed bags and poultry manure.

Factors affecting returns for both integrated contract and independent farms were farm size, live production (bird), production $(\mathrm{kg})$, mortality, average live weight $(\mathrm{kg})$, age of marketing (days), FCR, NP, doc, and feed costs. Analysis of income on integrated contract or independent farmers was carried out on cycle of production period from the entry of day-old-chicks until harvesting on day $35-42$.

\section{RESULTS AND DISCUSSION}

\section{Characteristics of Respondents}

Relevant information of respondents is presented in Table 1 to 3 . Owners of the poultry farms are predominantly people that are between $25-64$ years of age. About $43.3 \%$ of the integrated farmers were dominated by the age between 40 44 years, while independent farmers were dominated by the age between 35-39 years. Accordingly, integration model of poultry farming was adopted by young people (data not shown). It is interesting to note that majority of educational background of integrated farmers was university/college level (43.3\%), and junior high school was the least (Table 1). This indicates that integrated contract farming offered informal job for undergraduated people. While the independents were mostly operated by farmers with senior high school background. Experience in broiler farming was 1-10 years for most in integrated contract farmers whilst 1-5 and over than $11-15$ years were $37.5 \%$ for independent operation (data not shown). In addition, some integrated contract farmers have 20 years experience, and approximately $40 \%$ of the integrated contract farmers were the former of independent growers. Broiler farm businesses were run by various types of professions. Broiler producers are the main livelihood for farmers, the remaining is other professions such as entrepreneurs/self-employed, private teachers, civil servants and even members of parliament (Table 2). A large percentage of independent poultry farmers have a relatively small flock size that is below 2500 birds while most integrated poultry farms have a flock size that is relatively high (Table 3).

\section{Partnership Implementation}

There were three integrators as representative of the three large enterprises that operated this type of contract arrangement in East Lombok, West Nusa Tenggara dominating the poultry business: These are PT. Ciomas Adisatwa-CA (PT. Japfa Comfeed Indonesia Tbk), PT. Nusantara Inti Satwa-NIS (PT. Charoen Pokphand Indonesia) and UD Kartika Agro-KA. They had their own role, the contract agreement and implementation mechanism but the ultimate goals were similar. The differences in implementing the contract agreement of three firms were that NIS and KA employed the contract price and price guarantee but CA employed the market price or market mechanisms in providing all production inputs and in procuring live broilers. A deposit safety as a savings was implemented at the beginning of cooperation during ongoing partnership program by CA as much as IDR 2,000 per bird. When the decisions to leave for cooperation have been made, this savings can be taken back. 
Table 1. Educational Background of Integrated Contract and Independent Broiler Farmers from July to September 2011

\begin{tabular}{cccccc}
\hline & \multicolumn{2}{c}{ Integrated } & & \multicolumn{2}{c}{ Independent } \\
\cline { 2 - 3 } \cline { 5 - 6 } Education & $\begin{array}{c}\text { No. of respondent } \\
\text { (people) }\end{array}$ & $\%$ & & $\begin{array}{c}\text { No. of respondent } \\
\text { (people) }\end{array}$ & $\%$ \\
\hline Primary school & 4 & 13.3 & & 2 & 14.3 \\
Junior high school & 1 & 3.3 & & 1 & 7.1 \\
Senior high school & 12 & 40.0 & & 7 & 50.0 \\
University/college & 13 & 43.3 & & 4 & 28.6 \\
\hline Total & 30 & 100 & & 14 & 100 \\
\hline
\end{tabular}

Table 2. Main Occupation of Integrated Contract and Independent Broiler Farmers from July to September 2011

\begin{tabular}{lccccr}
\hline \multirow{2}{*}{ Main occupation } & \multicolumn{2}{c}{ Integrated } & & \multicolumn{2}{c}{ Independent } \\
\cline { 2 - 3 } \cline { 5 - 6 } & $\begin{array}{c}\text { No. of respondent } \\
\text { (people) }\end{array}$ & $\%$ & & $\begin{array}{c}\text { No. of respondent } \\
\text { (people) }\end{array}$ & $\%$ \\
\hline Broiler producer & 16 & 53.33 & & 11 & 78.57 \\
Farmer & 1 & 3.33 & & 0 & 0.00 \\
Entrepreneurs/ Self-employed & 4 & 13.33 & & 2 & 14.29 \\
State owned enterprises & 1 & 3.33 & & 0 & 0.00 \\
Civil servant & 7 & 23.33 & & 0 & 0.00 \\
Private teacher & 0 & 0.00 & & 1 & 7.14 \\
Member of Parliament & 1 & 3.33 & & 0 & 0.00 \\
\hline \multicolumn{1}{c}{ Total } & 30 & 100 & & 14 & 100 \\
\hline
\end{tabular}

Table 3. Farm Size of Integrated Contract and Independent Broiler Farmers from July to September 2011

\begin{tabular}{cccccrr}
\hline \multirow{2}{*}{ Scale } & \multicolumn{2}{c}{ Integrated } & & \multicolumn{2}{c}{ Independent } \\
\cline { 2 - 3 } \cline { 6 - 7 } & $\begin{array}{c}\text { Number of bird } \\
\text { (bird/cycle) }\end{array}$ & $\begin{array}{c}\text { No. of respondent } \\
\text { (people or \%) }\end{array}$ & & $\begin{array}{c}\text { Number of bird } \\
\text { (bird/cycle) }\end{array}$ & $\begin{array}{c}\text { No. of respondent } \\
\text { (people or \%) }\end{array}$ \\
\hline I & $2000-3500$ & $13(43.3)$ & & $\leq 2.500$ & $12(85.7)$ \\
II & $3500-5000$ & $11(36.7)$ & & $2.500-4.500$ & $2(14.3)$ \\
III & $>5000$ & $6(20.0)$ & & $>4500$ & none \\
\hline & Total & $30(100.0)$ & & & $14(100.0)$ \\
\hline
\end{tabular}

Farm Performance and Returns

Although incomparable between the two farming systems, the data obtained here is useful to give an idea on how both systems could encourage and continuously grow in different ways. In addition, poultry farming is able to 
Table 4. Performance of Broiler Farming in East Lombok of Integrated Contract and Independent Broiler Farmers from July to September 2011

\begin{tabular}{lcc}
\hline \multirow{2}{*}{ Description } & \multicolumn{2}{c}{ Performance } \\
\cline { 2 - 3 } & Integrated & Independent \\
\hline Population (bird) & 124.600 & 24.700 \\
Population/cycles (bird) & 4.153 & 1.764 \\
Rearing cycles/year & 6.0 & 5.4 \\
Production (bird) & 3.975 & 1.657 \\
Production (kg) & 7.983 & 3.390 \\
Feed (kg) & 13.878 & 5.646 \\
Mortality (\%) & 4.4 & 6.7 \\
Livability (\%) & 95.6 & 93.3 \\
Body weight /bird (kg) & 2.02 & 2.02 \\
FCR & 1.739 & 1.642 \\
Age at marketing (day) & 35.1 & 36.5 \\
Housing (m²) & 527.7 & 190.9 \\
Numerical Performance (NP) & 315.7 & 317.1 \\
\hline
\end{tabular}

increase the broiler population and to provide animal protein sources as well as to alleviate poverty for people with no job and for the small capital group. In general, performance of poultry farming run by both models of vertical integration and independent was quite reasonable when based on the important aspects of poultry management such as mortality, FCR, body weight, age of marketing and PN (Table 4). The different mortality is more likely due to the lack of attention and technical skill to health management particularly disease prevention through vaccination. For integrated contract farmers, the vaccination program was scheduled according to the company's recommendation. Whilst for the independent farmers, this study found that not all farmers do vaccination.

In terms of FCR and live body weight, three farm sizes showed almost similar performance in these parameters. Feed conversions were 1.757; 1.734 and 1.734 with body weight $2.04 \mathrm{~kg}, 1.98$ $\mathrm{kg}$ and $2.04 \mathrm{~kg} / \mathrm{bird}$ for scale I, II and III respectively (data not shown) with the average FCR and body weight (BW) were 1.739 and 2.02 $\mathrm{kg} / \mathrm{bird}$. While FCR of broilers achieved by the independent was 1.642 with BW $2.02 \mathrm{~kg} /$ bird. In other words, the performance of both systems is better than the integrator's standard (detailed not shown). This indicates that farmers have realized the importance of feeding efficiency from which loss and incentive can be obtained and feed is the largest cost of broiler production.

With regard to marketing and production cycles, integrated contract farmers were constant (6 times/year) regardless of fluctuations in market prices of input and output of broiler production. However, the production cycle of independent farms varied, from 3-6 times/year (data not shown) with the average was 5.4 times/year (Table 4). The decision made for producing broilers is dependent on market considerations as well as input and output prices when it is predicted to be profitable. The returns of independent farmers were IDR. 11,751,328/cycle or IDR.5,935,201 that was higher than the integrated farmers (Table 5). This is due to high sale price of live chickens when the study was undertaken, ranging between IDR.15,000 to IDR.17,500. However, the risk of loss is entirely borne by farmers. On the other hand, the returns of integrated contract farmers were lower if compared to independent farmers. This is in agreement with study reported by Windarsari (2007) and Yunus (2009) who conducted a study in Karanganyar, Central Java and Palu. Returns for vertical integration farmers are $26.56 \%$ lower 
Table 5. Costs and Returns (IDR) Poultry Farm in the Sample of Vertical Integration and Independent Farmers from July to September 2011

\begin{tabular}{|c|c|c|c|c|}
\hline & \multicolumn{2}{|c|}{ Integrated } & \multicolumn{2}{|c|}{ Independent } \\
\hline & IDR & $\%$ & IDR & $\%$ \\
\hline \multicolumn{5}{|l|}{ Fixed cost : } \\
\hline 1.Housing Depreciation & $1,038,542$ & 0.94 & 732,067 & 1.65 \\
\hline 2.Equipment depreciation & 171,771 & 0.16 & 95,073 & 0.21 \\
\hline 3.Maintenance & 90,833 & 0.08 & 77,857 & 0.18 \\
\hline Sub Total & $1,301,146$ & 1.18 & 904,997 & 2.04 \\
\hline \multicolumn{5}{|l|}{ Variable cost } \\
\hline 1. DOC & $19,154,333$ & 17.41 & $8,933,929$ & 20.13 \\
\hline 2. Feed & $82,953,960$ & 75.40 & $32,081,214$ & 72.29 \\
\hline 3. Vaccine & $1,323,948$ & 1.20 & 513,643 & 1.16 \\
\hline 4. Electricity & 235,000 & 0.21 & 165,357 & 0.37 \\
\hline 5. Litter & $1,095,817$ & 1.00 & 262,214 & 0.59 \\
\hline 6. Heater & $1,131,700$ & 1.03 & 438,929 & 0.99 \\
\hline 7. Labor & $1,609,583$ & 1.46 & 935,714 & 2.11 \\
\hline \multicolumn{5}{|l|}{ 8. Others } \\
\hline a. Transportation & 50,958 & 0.05 & 33,929 & 0.08 \\
\hline b. Harvest & 142,667 & 0.13 & 106,786 & 0.24 \\
\hline c. Out Operational cost & $1,017,067$ & 0.92 & 0 & 0 \\
\hline Sub Total & $108,715,033$ & 98.82 & $43,471,714$ & 97.96 \\
\hline Total production costs & $110,016,179$ & 100.00 & $44,376,712$ & 100.00 \\
\hline \multicolumn{5}{|l|}{ Revenues: } \\
\hline 1. Sales of broilers & $115,515,547$ & & $55,918,575$ & \\
\hline 2. Incentive & $2,053,224$ & & - & \\
\hline \multicolumn{5}{|l|}{ Others } \\
\hline 1.Used bags & 464,967 & & 158,036 & \\
\hline 2. Manure & 296,000 & & 51,429 & \\
\hline Total & $118,329,738$ & & $56,128,039$ & \\
\hline Total production costs & $110,016,179$ & & $44,376,712$ & \\
\hline \multicolumn{5}{|l|}{ Grower's income } \\
\hline 1. Chickens & $7,835,474$ & & & \\
\hline 2. Incentive & $2,053,224$ & & & \\
\hline 3. Used bags & 464,967 & & & \\
\hline 4. Manure & 296,000 & & & \\
\hline Gross income & $10,649,665$ & & & \\
\hline Expenses & $4,833,538$ & & & \\
\hline Net cash income & $5,816,127$ & & $11,751,328$ & \\
\hline
\end{tabular}

than self-capital farmers (Windarsari, 2007). The present study is in contrast to the previous research reported by Begum (2005a) and Begum $(2005 b)$ that net returns of the contract farm 
calculated per bird was more than 1.7 times higher than the net returns of the independent farm. In addition, the farms under vertical integration are more efficient in terms of profit earning than the independent farms. In the present study, net returns were calculated on farm basis or per production cycle, it was not per bird and again that the independent farmer took advantage of the high price in the market when this study was undertaken. This is probably the reason why returns for the integrated contract farmers were lower than the individual farmers. Cunninghum (1997) indicated that returns for contract broilers were consistently less variable than those selected for agricultural products. This was supported by Patrick (2004) that price of broilers in Lombok showed quite wide fluctuation and contracted farmers were paid under the contract which was higher than the price market.

Numerical performances of farm size I, II and III are $312.2 ; 316.2$, and 322.2 or the average is 315.7, meanwhile NP of independent farmers is 317.1. Thus, NP values achieved either integrated contract or independent farms are higher than 200 as a standard NP. It means that operational management of both farming systems are better and more efficient in the use of feed associated with the cost efficiency of farmers.

\section{Advantages and Disadvantages of Both Systems}

Empirically in the study showed that the integrated model was not always profitable and sometimes, even, they lose the money, but they persisted in this pattern for many reasons. Firstly, vertical integration offered a stable income and the second was that risk sharing which the risk was not borne by them and the firms were also responsible to the problems. The potential advantages to farmers into integration are that farmers are very beneficial, especially for farmers who are limited to the provision of the capital. Through a cooperative partnership, they do not need to spend any capital for this agribusiness which is still a major constraint for investment in the broiler farm. Then, the stability of income due to reduced production and marketing risks is important. Increased efficiency through technical assistance, management, market knowledge and access to technology were another advantages. Security related to the grade and market due to product standards is met and lastly, the access to the capital is easier because most of inputs to be met by firms, and this enable the integrated contract farmers can enlarge the business scale.

Taking into consideration the weaknesses in the partnership, these are three important aspects to be considered. Firms to some extent seemed more dominant over the farmers, as a consequence some farmers decided to leave from the cooperation. The lack of trust between both parties and loss of flexibility as well as the company's losses are often due to unacceptable behavior of farmers and the high cost of distribution and service. Priyono et al. (2004) points out that the weaknesses of the implementation of the partnership is that over supply of integrator could happen when chickens are simultaneously harvested at the same time. As for growers, at fixed pricing imposed by integrators, they do not get the maximum profit because of tied agreement with the integrators and the input prices are too high. Poultry management on their own also has advantages and disadvantages. Some of the advantages are free to set the management of farm businesses, raising broilers is easy and relatively short time, the growers can independently manage their farm better and more diligent so that maximum performance can be obtained. The disadvantages are that they face a risk in the process of production and marketing, no guarantee and no technical guidance are available, often constrained in the capital; therefore, shortages in poultry farm needs are difficult to the expansion. Finally, growers tend to be speculative and incorrect speculation lead to a great loss.

Regardless of these facts, this study found that integrated contract poultry farming is beneficial for the growers in providing a job and in increasing income. These results are similar to the study reported in other countries by Bamiro et al. (2009) who examine the economic value of integrated model and profitability in poultry industry in Nigeria and Begum (2005a) in some districts in Bangladesh. From economic point of view, broiler farming is one of agribusiness that offers benefits (Suharno, 2002). Independent farming model is promising to increase the income of small-scale farmers and it should be made into a model of economic empowerment of the people. However, the capital constraints facing small-scale farmers have not fully became the attention of governments and banking institutions. Banks seem very difficult to disburse funds or credit for a small scale but more interested to large businesses or other productive ventures. The point is that raising chickens is a 
risky business because there was no guarantee all chickens would live up to the harvest. This is the fact that independent farmers had difficulties in obtaining credit because no valuable guarantees are offered, even farmer's business credit, which is now available and have put into the government's policy.

\section{Government Involvement and Association}

This study also observed and recorded that there was dissatisfaction and complaints such as unscheduled harvesting, short period of rearing which reduce their income when the maximum growth rate of broilers have not been met. Although some integrated farmers were not satisfied by the model, the integrated contract poultry farming is promising for a group with limited capital, skill and knowledge. Overall, the three companies have established a good cooperation in East Lombok. However, it seems that the role of government as an institution or a third party that may serve as a facilitator is lack. It should be as a mediator when there is a dispute or problems in the cooperation. The government's role in the development effort is quite important in poultry agribusiness both in giving way business licenses as well as monitoring and educating which bring about to business sustainability such as production, breeding, processing and marketing (Presidential Decree. No. 22 in 1990). Following lifting this Presidential Decree with Presidential Decree No. 50 in 2000, this sort of business is no longer regulated, and as a consequence, Law No. 18 in 2009 on Animal Husbandry and Animal Health is pursued. The government should refer to statement in Law No 18 of 2009 section 29 (2) which are intended to protect the domestic or local business from unhealthy competition among market participants. Further to Article 31 (3), the central and local governments should guide the partnership as referred to paragraph (2) with respect to the provisions of legislation in the field of business partnerships. Evaluation on how much freedom or autonomy contract grower operation to the farmers in terms of implementing a grant and incentive should be carried out to provide a conducive business environment. In this survey, again that the role of government on small-scale farmers is lack and the integrated contract operation is uncontrolled. As mentioned that this study did not focus on the farmer's perception to the integrated contract agreement but more concern on performance, returns and relevant information to improve the existing systems. Therefore, a favorable environment for domestic and foreign investment to offer opportunities for more positive competition among firms and selfcapital producers should be provided and to be taken into a encouraging policy. Also, the existing association is expected to work and inform all aspects of poultry business such as market information, export opportunities if possible and strengthen the association. It is necessary to know that there are two associations in East Lombok, APKINDO (Asosiasi Peternak Kecil IndonesiaAssociation of Indonesia Small Farmers) which was established in 2002 whose members are integrated farmers and independents, and APBAsosiasi Peternak Broiler (Broiler Grower Association) East Lombok that was established in 2004. Unfortunately, the existence of the two associations has not been maximized.

In spite of such constraints agribusiness, both systems remains beneficial and profitable in providing jobs and in reducing unemployment problems. As stated by Jabbar et al. (2008) that commercial poultry production was a reasonable option for income and employment generation and also helped to diversify the income of both independent and contract poultry farmers.

\section{CONCLUSION}

The development of integrated contract and independent broiler production in East Lombok, regardless of the constraints, is profitable and beneficial for people with some limitations such as skill, knowledge, and capital. Numerical performances of both systems are reasonable. Returns for integrated contract farmers were lower than those independent farmers based on the production cycle. Particularly in this region, integrated contract broiler farming is promising for graduated people in providing informal job. The role of government should involve in encouraging and assisting the small scale farmers to enter a large scale.

\section{ACKNOWLEDGMENT}

This paper is partly derived from a study of Suryatman who undertook Magister of Animal Resources Management and it has been permitted to publish. Authors would like to thank all those involved in this study. 


\section{REFERENCES}

Bamiro, O. M., S. Momoh and D. O. A. Phillip. 2009. Vertical integration and profitability in poultry industry in Ogun and Oyo States, Nigeria. J Hum. Ecol., 27(2): 149-154.

Begum, I. A. 2005a. An assessment of vertically contract poultry farming: A case study in Bangladesh. Inter. J. Poult. Sci. 4 (3): 167176. http: //www.pjbs.org/ ijps/ fin332.pdf

Begum, I. A. 2005b. Vertically integrated contract and independent poultry farming system in Bangladesh: a profitability analysis. Livestock Res. Rural Dev. 17 (8). http://www.lrrd.org/lrrd17/8/ara17089.htm

Costales, A. and M. A. O. Catelo. 2009. Contract farming as an institution for integrating rural smallholders in markets for livestock products in developing countries: (II) Results in case countries. PPLPI . Research Report, Nr. 09-04

Cunningham, D. L. 1997. Contract broiler grower returns: A long-terms assessment. J. Appl. Poult. Res. 6: 267-273.

Goodwin, Jr. H. L., B. L. Ahrendsen, T. L. Barton and J. H. Denton. 2005. Estimated returns for contract broiler production in Arkansas, Missouri, and Oklahoma: Historical and future perspectives. J. Appl. Poult. Res. 14: 106-115.

Jabbar, M. A., M. H. Rahman, R. K. Talukder and S. K. Raha. 2008. Alternative institutional arrangements for contract farming in poultry production in Bangladesh and their impacts on equity. Research Report 7. International Livestock Research Institute.

Patrick, I. 2004. Contract farming in Indonesia: Smallholders and agribusiness working together. Aciar Technical Reports, 54. www.ruralfinance.org/1120037627274_contr
act_farming_Indonesia.pdf

Thamizh, S. R. K and S. V. N. Rao. 2009. Farmer's perceptions on contract broiler farming. Indian J. Poult. Sci. 44 (2): 243248.

SAPPLPP-South Asia Pro Poor Livestock Policy Programme. 2009. Vertical integration at Suguna poultry farms: A critical look at pro poor livelihood issues. http://www.fao.org/docrep/006/y5098e/y509 8e04.htm.

Simmons, P., P. Winters and I. Patrick. 2005. An analysis of contract farming in East Java, Bali and Lombok, Indonesia. Agri. Econ. 33. Suppl. 513-525

Sriboonchitta, S. and A. Wiboonpoongse. 2008. Overview of contract farming in

Thailand: Lessons learned. ADBI discussion paper 112. Tokyo: Asian Development Bank Institute. http://www.adbi.org/discussionpaper/2008/07/16/2660.contract.farming.thai land/Asian Development.

Tatlidil, F. F. and D. Aktũrk. 2004. Comparative analysis of contract and non contract farming model in tomato production. J. Agronom. 3 (4): 305-310.

Undang-Undang Republik Indonesia Nomor 18 Tahun 2009 Tentang Peternakan dan Kesehatan Hewan. http://www.deptan.go.id.

Windarsari, L.W. 2007. Kajian usaha peternakan ayam ras pedaging di Kabupaten Karanganyar: Membandingkan antara pola kemitraan dan pola mandiri. Tesis. Sekolah Pascasarjana Institut Pertanian Bogor.

Yunus, R. 2009. Analisis efisiensi produksi usaha peternakan ayam ras pedaging pola kemitraan dan mandiri di Kota Palu Provinsi Sulawesi Tengah. Tesis. Program Pascasarjana Universitas Diponegoro Semarang. 